УДК 346:658.115.31

https://doi.org/10.32689/2708-7530-2020-2(2)-16-28

Жук Вікторія Петрівна кандидат наук $з$ державного управління, доцент кафедри індустрії гостинності та сталого розвитку, навчально-наукового інституту управління, економіки та природокористування Таврійського національного університету імені В.I. Вернадського, 03162, м. Київ, вул. Тулузи, 16, кв.284, тел.: (067) 404-76-64, e-mail: japha@ukr.net, https://orcid.org/0000-0002-3284-959X

\title{
ДЕРЖАВНЕ ПАРТНЕРСТВО У СФЕРІ ЖИТЛОВО-КОМУНАЛЬНИХ ПОСЛУГ
}

Анотація. Сучасний етап розвитку світової економіки, що характеризується, 3 одного боку, все більш наростаючими темпами глобалізації, а 3 іншого - складними кризовими явищами, зростанням безробіття, величезним різницею у рівнях соціально-економічного розвитку країн і окремих регіонів, вимагає переходу на новий рівень управління, пошуку нових інститутів розвитку, нових політичних, економічних, правових i організаційних регуляторів.

Різні країни шукають різні способи розвитку Національні економіки, в тому числі і відмовляються від чисто ринкових механізмів. Більш перспективним напрямком $\epsilon$ пошук такої взаємодії держави і приватного сектора, яке, з огляду на національні особливості і рівень розвитку країни, сприяло б ії соціально-економічному розвитку. Ця проблема $є$ актуальною і для України.

Сфера житлово-комунальних послуг України в даний час потребує серйозних змін: технічне переоснащення, організації ефективного управління, демонополізації і створення умов для конкуренції, а також правового та науково-технічного забезпечення реформування галузі.

Чинне законодавство, що регулює надання житлово-комунальних послуг в Україні, багато в чому не відповідає ні фактично сформованим у цій сфері правовідносин, ні європейським стандартам, що, в свою чергу, не сприяє залученню іноземного капіталу для розвитку тих об'єктів, які дійсно цього потребують. Одним з найважливіших соціально-економічних перетворень, що відбуваються в даний час в Україні, є реформування та розвиток житловокомунального господарства. Актуальність невідкладного вирішення завдань по 
реформуванню діяльності підприємств житлово-комунального господарства обумовлена надзвичайною гостротою проблем, що накопичилися в цій сфері.

Необхідне вдосконалення технічного оснащення комунальних підприємств та модернізація інженерних комунікацій, а також забезпечення підвищення доступності послуг житлово-комунальних послуг для всіх верств населення $\mathrm{i}$ кожного окремого споживача.

Житлово-комунальне господарство в сукупності 3 громадською інфраструктурою є складовою комплексу надання громадських послуг. Для України складність управління даним сектором пов'язана з рядом причин, серед яких значна площа території, постійні трансформації економічної системи, практично повна приналежність об'єктів інфраструктури державним, а також регіональним і муніципальним органам влади.

Ключові слова: житлово-комунальні послуги, житлово-комунальне господарство, державно-приватне партнерство, інфраструктура співпраці.

Zhuk Victoriia Petrovna associate professor of department of Hospitality Industry and Sustainable Development", Educational and Scientific Institute of Agministration, Economics and Nature Management of V.I. Vernadsky Taurida National University, 03162, Kyiv, street Toulouse, 16, apt. 284, tel.: (067) 404-76-64, e-mail: japha@ukr.net, https://orcid.org/0000-0002-3284-959X

\title{
SOVEREIGN PARTNERSHIP IN THE SPHERE OF HOUSING AND COMMUNAL SERVICES
}

\begin{abstract}
The current stage of development of the world economy, that is characterized by, on the one hand, permanently increasing paces of globalization and on the other - complex crisis, increasing unemployment, huge difference between levels of socio-economic development of countries and regions, requires change to a new level of management, searching for new development institutions, new political, economic, legal and organizational regulators.

Different countries are looking for different ways to develop national economies, including rejection of market mechanisms. A more prospective direction is the search of such interaction between state and private sector, that taking into account national features and level of development of the country, would contribute to its socio-economic development. This problem is also relevant for Ukraine.

Housing and utilities sector of Ukraine currently needs serious changes: technical reequipment, organization of effective management, demonopolization and
\end{abstract}


creation of conditions for rivalry, as well as legal, scientific and technical support for reforming the industry.

The current legislation that governs housing and utility sector in Ukraine, in many respects does not meet either actual legislation established in this area or European standards, this does not contribute to attracting foreign capital for the development of those facilities that really need it. One of the most important socioeconomic transformations, that currently takes place in Ukraine, is the reform and development of housing and utilities sector. The urgency of immediate solution of reforming housing and utilities sector is based on the extreme depth of the problems that have accumulated in this area.

It is necessary to improve and modernize technical equipment of utilities, as well as increase the availability of housing and utilities sector for all segments of the population and each individual consumer.

Housing and utilities sector in combination with public infrastructure are part of the complex of public services provision. For Ukraine, the problem of managing this sector is connected with a number of reasons, including large area, constant transformation of the economic system, almost full ownership of infrastructure facilities to state, as well as regional and municipal authorities.

Key words: housing and utilities sector, public-private partnership, cooperation infrastructure.

Постановка проблеми. Жалюгідний стан комунальної інфраструктури в Україні змушує розглядати різні можливості залучення приватних інвестиційних ресурсів до ii розбудови i реконструкції. 3 огляду, що приватизація цієї інфраструктури не $є$ найкращою можливістю, 3 огляду на втрату публічного контролю за наданням базових громадських послуг населенню, як оптимальний може розглядатися варіант концесії на об'єкти інфраструктури ЖКГ i надання послуг тепло-, водопостачання, вивозу й утилізації сміття.

Проект передачі об’єктів і послуг теплопостачання започаткований у Львові за участі Бюро економічного менеджменту i правових досліджень ВСЕОМ, Франція), ще у 2003 році. Згідно із здійсненим техніко-економічним обгрунтуванням, експертами було рекомендовано модель концесії для системи теплопостачання і надано допомогу для підготовки договору про концесію. За оцінками експертів, сума необхідних інвестицій у модернізацію системи теплопостачання складає приблизно 400 млн. грн., а відповідний проект може бути завершеним упродовж 4 років 
Також в Україні існують прецеденти укладання договорів з приватним партнером щодо надання певного виду (видів) комунальних послуг.

Указом Президента України № 895 затверджено національні пріоритети (“Нова енергія”, “Нова якість життя”, “Нова інфраструктура", “Олімпійська надія 2022”), а в грудні 2010 р. КМУ затвердив перелік “Національних проектів" з пріоритетних напрямків соціально-економічного розвитку держави, що були запропоновані Укрнацпроектом. У результаті вперше було закріплено принципово новий проектний підхід державного управління, яким запроваджується персональна відповідальність і конкретні терміни реалізації поставлених завдань, а також створений практичний механізм для реалізації державно-приватного партнерства, затверджений Законом України "Про державно-приватне партнерство".

На жаль, до списку національних проектів, які не увійшли, щонайменше, ще три проекти, кожен з яких, з нашої точки зору, заслуговує на особливу увагу в умовах проголошеного курсу на модернізацію економіки й зовні виглядає таким же привабливим для інвестицій, як і деякі із затвердженого плану. Зокрема, це такі проекти:

1) “Циклон-4” - створення космічного стартового ракетного комплексу;

2) "Індустріальні парки" - створення спільних промислових зон;

3) “Київське кільце” — будівництво великої кільцевої автомобільної дороги в м. Києві;

Передбачається, що визначені до реалізації національні проекти поліпшать ділову репутацію України за рахунок досягнення наступних показників:

- залучення 14-15 млрд дол. прямих іноземних інвестицій;

- створення не менше 300 тис. нових робочих місць;

- досягнення збільшення ВВП на 4,7-5\%;

- зменшення щорічних витрат на імпорт енергоресурсів на 2 - 2,5 млрд дол.;

- зменшення енергоємності ВВП на 10-12\%;

- створення імпульсу для економічного, соціального та тереторіального розвитку;

- створення сприятливого інвестиційного клімату та позитивного іміджу держави;

- наближення перспективи входження до $\mathrm{G}-20$.

Нам вбачається, що розробка та запровадження "національних проектів", які розглядаються як комплекс стратегічно орієнтованих заходів, спрямованих на комплексне вирішення найбільш актуальних завдань системної модернізації 
суспільства, свідчить також про поступовий перехід від реактивної моделі управління державою до прогресивного i передбачуваного стратегічного планування соціально-економічного розвитку національної економіки. Окрім того, на прикладі реалізації національних проектів можна відпрацювати механізми, які стануть основою майбутньої інвестиційної реформи в Україні.

Джерелом ресурсів для реалізації національних проектів має стати поєднання безпосереднього витрачання бюджетних коштів (не більше як 20\%) та залучення коштів приватних вітчизняних і іноземних інвесторів на підгрунті відповідної заохочувальної та інформаційно-методичної політики держави, а також ймовірне залучення коштів міжнародних організацій, призначених на підтримку структурних реформ в Україні.

В усіх визначених національних проектах держава має намір брати участь шляхом оплати попереднього ТЕО, інженерної інфраструктури, запровадження пільгових тарифів і надання держгарантій, що дозволить створити механізми ефективного партнерства 3 приватними інвесторами у фінансовому забезпеченні стратегічних проектів розвитку держави, зменшить навантаження на бюджет та забезпечить ефективне залучення дешевих кредитних ресурсів.

Аналіз останніх досліджень і публікацій. Особливості функціонування ЖКГ в умовах ринку досліджували багато вітчизняних і зарубіжних вчених: Д.Віккерс, П.Габор, Д.Гарднер, А.Кумара, Д.Лоран, М.Бардіна, В.Шаркі, Д.Яроу, А.Бабак, Р.Мартусевич, Ю.Манцевич, Н.Олійник, О.Романюк, С.Сиваєв, Д.Хомченко та ін. Зазначені автори зробили важливий внесок у розробку концептуальних засад i механізмів державного управління різними сферами соціально-економічного розвитку в умовах системних трансформацій суспільства. Водночас розгортання світової фінансово-економічної кризи справляє вплив на перспективи розвитку державно-приватного партнерства, змінює баланс вигод та витрат сторін партнерства, що потребує відповідного науково-теоретичного узагальнення.

Мета статті - дослідити реалізацію механізму державно-приватного партнерства у сфері житлово-комунальних послуг 3 метою формування ефективної інфраструктури співробітництва держави і бізнес-спільноти

Виклад основного матеріалу. Комунальні підприємства завдяки своєму статусу комерційних підприємств на свій розсуд мають право укладати контракти на виконання певних робіт з іншими підприємствами, відповідно до Господарського кодексу України зі змінами та доповненнями. При укладанні контракту на надання послуг комунальне підприємство делегує виконання певних функцій приватній компанії на певний період часу. Загальна відповідальність за надання комунальних послуг залишається за державним 
підприємством, але фактично робота виконується приватною компанією. Контракти щодо виконання певних робіт підприємствами у сфері ЖКП як форма державно-приватного партнерства доцільно укладати при виконанні наступних дій:

- при значних обсягах часто повторюваних робіт (наприклад, виставлення рахунків споживачам, збирання платежів, зчитування показників лічильників, очищення каналізаційних систем) укладання контрактів особливо вигідне підприємствам $з$ великою кількістю працівників;

- при технічному обслуговуванні спеціалізованого обладнання (наприклад, насосів на насосних станціях або іншого складного обладнання водоочисних станцій);

- при виконанні робіт, що належать до непрофільних видів діяльності комунальних підприємств і потребують від них високих, з огляду на масштаби цих робіт, витрат (наприклад, прання спецодягу, утримання їдальні, технічне обслуговування автотранспортних засобів, лабораторний аналіз тощо).

Укладання контрактів щодо виконання робіт $\epsilon$ привабливими для державних установ, відповідальних за надання комунальних послуг, за умови сприяння скороченню витрат та заощадження коштів завдяки економії на масштабі. [1]

При здійсненні такої форми державно-приватного партнерства, як укладання контрактів на виконання робіт підприємствами у сфері ЖКП, доцільно враховувати такі організаційно-економічні механізми:

-сформувати перелік робіт для укладення контрактів на виконання робіт;

-провести зональне, технологічне та процесне подрібнення робіт проектів;

-сформувати докладний обсяг робіт за контрактом; установити межі відповідальності сторін;

-провести конкурс серед приватних підприємств для укладення контрактів на виконання робіт.

Як різновид контракту щодо виконання робіт у сфері ЖКП може бути застосований аутсорсінг, тобто делегування власником комунального підприємства певних бізнес-процесів чи виробничих функцій на обслуговування приватному підприємству, яке спеціалізується у відповідній галузі.

На відміну від звичайного контракту на виконання робіт, які мають разовий, випадковий характер, на аутсорсінг передаються зазвичай функції із професійної підтримки безперервного функціонування окремих систем на основі довгострокового контракту (не менше одного року). Найпоширенішими видами аутсорсінгу $\epsilon$ передача таких функцій: бухгалтерський облік, 
управління інформаційними системами, бізнес-планування та оптимізація процесів, послуги доставки, тестування, прибирання та обслуговування, коллцентрів (обробки телефонних викликів та передача на сторону).

За умови застосування такої форми державно-приватного партнерства, як договір на управління підприємством, комунальне підприємство покладає на приватну компанію відповідальність за виконання всіх завдань, пов'язаних 3 управлінням функціонування підприємства. Послуги приватної компанії оплачуються здебільшого у фіксованому розмірі, вона бере на себе більший комерційний ризик, ніж при використанні такої форми державно-приватного партнерства, як контракти на виконання робіт. Приватна компанія може нести витрати на дрібний ремонт і незначну реконструкцію устаткування. Зазвичай контракти цього типу є середньостроковими (5-10 років).

При використанні такої форми державно-приватного партнерства, як договір на управління підприємством у сфері ЖКП, доцільно враховувати такі організаційно-економічні механізми:

- залучити як партнерів міжнародні спеціалізовані фірми з управління підприємствами у сфері житлово-комунального господарства, що надасть можливість впровадження технологічних та управлінських інновацій у функціонування вітчизняного комплексу ЖКГ;

- сформувати та залучити колектив менеджерів з управління окремими напрямками, процесами та проектами підприємств у сфері ЖКГ;

- функції стратегічного управління та капітальних інвестицій можливо залишити за комунальним підприємством;

- власник комунального підприємства несе відповідальність за неспроможність приватного підприємства, залученого до управління, задовольнити вимоги встановлених державних стандартів надання комунальних послуг.

При використанні лізингу як форми державно-приватного партнерства відповідно до Закону України «Про фінансовий лізинг» (зі змінами i доповненнями) комунальне підприємство може надати лізингоодержувачу в користування на встановлений термін майно, що є власністю підприємства. У випадку оперативного лізингу лізингоодержувач оплачує користування майном за фіксованою ставкою i отримує, таким чином, стимул до ефективної експлуатації майна і скорочення експлуатаційних витрат. Об’єктом лізингу можуть бути тільки основні фонди комунального підприємства.

При використанні такої форми державно-приватного партнерства, як лізинг, у сфері ЖКГ доцільно враховувати такі організаційно-економічні механізми: 
- власник комунального підприємства може на конкурсній основі передати майно в лізинг приватній компанії;

- комунальне підприємство несе відповідальність за надання комунальних послуг, установлення тарифів та якість окремих аспектів обслуговування споживачів;

- усі надходження понад здійснені витрати залишаються в розпорядженні приватного підприємства;

- приватне підприємство має звітувати перед власником комунального підприємства або уповноваженим ним органом;

- приватне підприємство отримує можливість зниження ризиків оперативної діяльності за рахунок комунального підприємства;

- приватне підприємство може віднести лізингові платежі на витрати, що знижує прибуток до оподаткування;

- право власності на обладнання залишається за комунальним підприємством.

Незадовільні показники фінансово-економічного стану українських комунальних підприємств роблять оренду, лізинг та інші прогресивні форми залучення приватного сектору в нинішніх умовах непривабливими. Зокрема, об'єктом оренди відповідно до Закону України «Про оренду державного та комунального майна» (зі змінами та доповненнями) може бути як окреме визначене майно, так і цілісний майновий комплекс (ціле підприємство), а орендна плата за оренду цілісних майнових комплексів, їх структурних підрозділів та нерухомого майна, яке перебуває в комунальній власності, зараховується до місцевого бюджету і повинна використовуватись на капітальні вкладення. Орендна плата за індивідуально визначене майно, яке здається в оренду підприємством у порядку, встановленому законодавством та статутом підприємства, спрямовується на поповнення обігових коштів підприємства. [2]

При використанні такої форми державно-приватного партнерства, як оренда, у сфері ЖКГ доцільно зазначити:

- особливо привабливою формою державно-приватного партнерства $\epsilon$ оренда у сфері ЖКГ для підприємств, що мають пільговий тариф на природний газ;

- право власності на майно залишається за приватним підприємством;

- орендні платежі у порівнянні з лізинговими є значно меншими, оскільки замовник у даному випадку не сплачує вартість обладнання;

- усі ризики проекту покладаються на приватного інвестора, основним способом зниження ризиків $є$ укладення договорів довгострокової оренди. 
В Україні з метою поступового переходу від монопольного стану до ринкового в системі тепло забезпечення та теплопостачання, а також забезпечення часу для адаптації споживачів та виробників до нових умов виникає обгрунтована необхідність використання перехідних моделей організації ринку. Серед таких моделей є модель єдиного покупця, яку доцільно застосовувати за умови:

- невеликої кількості постачальників порівняно з кількістю споживачів;

- структури укладених угод, яка не підлягає частій зміні;

- можливості реалізації конкуруючих довгострокових проектів виробництва тепла.

У системі тепло забезпечення та теплопостачання модель єдиного покупця використовується для побудови та організації відносин, у яких присутні підключені до єдиної теплової мережі джерела тепла, що належать різним власникам. Сдиний покупець проводить конкурсний відбір джерел теплової енергії для закупівлі в них теплової енергії та (або) потужності для продажу споживачам.

Для більш широкого впровадження форм державно-приватного партнерства в системі ЖКП України необхідно створити Національний реєстр об'єктів за відповідними територіями, секторами, процесами та проектами системи ЖКП, а також сформувати економічний механізм добровільної сертифікації систем управління, процесів, проектів, технологій, послуг та персоналу в сфері ЖКП. Така система спрямована на підвищення якості управління в цій галузі, реалізацію комплексного моніторингу розвитку та функціонування всіх об’єктів ЖКП, розвиток системи підвищення кваліфікації спеціалістів ЖКГ та інших. Об’єктами сертифікації можуть виступати послуги окремих організацій чи їх персонал, які здійснюють діяльність у сфері ЖКП. Підприємствам, що пройшли сертифікацію у сфері ЖКП, може надаватися пріоритетність чи переваги в конкурсах державного або тереторіального замовлення. Зазначені заходи підвищуватимуть конкурентоспроможність та статус організації при здійсненні діяльності в конкурентному середовищі.

Найбільш ефективним шляхом зниження вартості житлово-комунальних послуг, зокрема у сфері теплопостачання, $\epsilon$ енергозбереження. Щорічне споживання природного газу в сфері ЖКП становить 10-12\%, а електроенергї 5-6\% від їх загальнодержавного споживання. Через незадовільний стан обладнання i застарілі технології втрачається до 30-40\% спожитих енергетичних та матеріальних ресурсів. 3 іншого боку, немає реальних стимулів до економії ресурсів. 
Відтак, одним із провідних напрямків підвищення ефективності функціонування системи тепло забезпечення та теплопостачання $\epsilon$ удосконалення механізму енергогосподарювання. 3 вищезазначених позицій у межах формування системи державно-приватного партнерства доцільно залучати енергосервісні компанії, які здатні відіграти важливу роль у фінансуванні розвитку сектору теплоенергетики в Україні. [3] Енергосервісні компанії можуть бути як державної, так і приватної власності. На сьогодні в Україні ринок приватних енергосервісних компаній недостатньо розвинутий. Контракти 3 такими приватними підприємствами можуть стати ефективними засобами фінансування заходів зі збільшення енергоефективності. Мета енегосервісної компанії - реалізація комплексних рішень, спрямованих на скорочення витрат енергозбереження, а оплата іï діяльності пов’язана 3 ефективністю реалізованих рішень. Енергосервісна компанія може реалізовувати фінансування проектів, спрямованих на енергозбереження, самостійно або із залученням третьої сторони.

Енергосервісна компанія може здійснювати такі послуги:

- енергетичний аудит та аналіз стану об'єкта;

- розробку та реалізацію проектів енергозбереження в секторі теплозабезпечення та теплопостачання;

- проектування та установку обладнання й устаткування;

- розробку бізнес-планів, спрямованих на отримання комунальним підприємством фінансування проектів енергозбереження в секторі теплозабезпечення та теплопостачання;

- управління та експлуатацію;

- моніторинг енергозбереження.

У світовій практиці використовуються такі форми партнерства 3 енергосервісними компаніями:

- контракт на підвищення енергоефективності, або «енергетичний перфоманс - контракт» (енергосервісна компанія розробляє та реалізує проекти 3 підвищення енергоефективності; бере на себе частину ризиків, що пов'язані 3 підвищенням енергоефективності; дохід, пов’язаний зі зниженням витрат, може використовуватися на оплату послуг енергосервісної компанії або розподілятися відповідно до досягнутих домовленостей);

- контракт на енергоефективне управління енергосистемою з гарантованим результатом (енергосервісна компанія не тільки розробляє та реалізує проекти 3 підвищення енергоефективності, а й покладає на себе відповідальність за забезпечення визначеного рівня енергозбереження, а також управляє експлуатацією системи продажу енергоресурсів). 
Окремим вагомим напрямком удосконалення системи тепло забезпечення та теплопостачання на базі системи державно-приватного партнерства та інструментом стимулювання енергозбереження має стати проведення державного комплексного енергоаудиту систем тепло забезпечення та теплопостачання з економічною оцінкою варіантів розвитку систем, незалежно від теплозабезпечуючих організацій. Зазначений енергоаудит дозволить оптимізувати витрати, а також не лише виявити потенціал енергозбереження системи тепло забезпечення та теплопостачання, а й сформувати конкретні бізнес-плани на кредити для впровадження енергоефективних технологій та модернізацію обладнання. Комплексний енергоаудит системи тепло забезпечення та теплопостачання міст і територій має виявляти необхідні схеми резервування, оптимальне завантаження теплоджерел, шляхи мінімізації втрат тепла, в тому числі за рахунок зменшення трубопроводів. Енергоаудит може також застосовуватися для фінансово-технологічного контролю суб'єктів природних монополій.

Доцільними інструментами стимулювання енергозбереження в системі тепло забезпечення мають стати:

- організація моніторингу програм із підвищення енергоефективності, 3 виокремленням отриманої економії на окремі рахунки, що дозволить реально оцінити результати виконання проектів, внесення коректив та врахування необхідних змін у майбутньому;

- розробка та впровадження механізмів мотивації персоналу до енергозбереження та енергоефективного управління, персонального заохочення за економію та покарань за перевитрати паливно-енергетичних ресурсів на підприємствах усього ланцюга тепло забезпечення;

- створення системи стимулювання кредитування енергоефективних проектів;

- підвищення економічності роботи котельних шляхом переведення їх iз дефіцитного та дорогого палива на газ та інші види палива;

- комплексного впровадження автоматизованих систем диспетчерського управління та контролю.

Отже, впровадження механізмів державно-приватного партнерства в галузі житлово-комунального господарювання дозволить досягти наступних результатів:

- підвищити ефективність операційної діяльності підприємств, окремих процесів та проектів;

- впровадити техніко-технологічні, управлінські еколого-економічні та соціальні інновації; 
- залучити додаткові фінансові, матеріальні та інформаційні ресурси;

- забезпечити підвищення якості надання комунальних послуг;

- підвищити потенціал платоспроможності підприємств ЖКГ;

- збільшити інвестиційну привабливість підприємств ЖКГ та окремих проектів;

- удосконалити механізм модернізації систем ЖКГ;

- підвищити сталість розвитку підприємств ЖКГ та ефективність процесів надання комунальних послуг.

Різноманітність видів, форм і сфер застосування державно-приватного партнерства роблять його універсальним механізмом для рішення цілого ряду довгострокових задач - від створення і розвитку інфраструктури до рішення розробки i адаптації нових перспективних технологій.[1] Істотну роль у розширенні державно-приватного партнерства повинно зіграти подальше удосконалення законодавчої і нормативної бази, у тому числі на підставі як позитивних, так і негативних результатів спроб сформувати таке партнерство. Крім того, для забезпечення припливу приватного капіталу в інфраструктурні проекти, держава повинна створювати прийнятний для обох сторін баланс ризиків і винагород, а також враховувати прояви позицій некомерційних організацій, бізнес-структур при спільній взаємодії і здійснювати аналіз стану партнерських відносин на основі інтегрованих вимірів.

Висновки. Сфера ЖКГ в процесі реформування вимагає значного обсягу інвестицій, моніторингу процесів оновлення 3 боку державних органів, прозорості в цілях реалізації розвиток науково-технічної революції, визначальною технологічне переозброєння галузі, зростаюча відкритість економічних систем державно-приватне партнерство інтересів населення та участі суб'єктів бізнес-спільноти в соціально значущих проектах. Усе це підтверджує необхідність і можливість використання механізму державноприватного партнерства як основи формування ефективної інфраструктури співробітництва в системі житлово-комунальних послуг.

\section{Лimepamypa:}

1. Бульбас С. Порятунок сфери ЖКП - державно-приватне партнерство//[Електронний pecypc]. - Режим доступу: http://www.uspp.org.ua/interview/17.poryatunok-sferi-zhkgderzhavno-privatne-partnerstvo.htm

2. Федотова Ю.В., Моря А.О. Державне регулювання житлово-комунального господарства України: світовий досвід та перспективи господарстві. - [Електронний ресурс]. - Режим доступу: http://ojs.kname.edu.ua/index.php/area/article/view/757

3. Про загальні засади державно-приватного партнерства: Законопроект України від 25 черв. 2009 p. [Електроннийресурс]. - Режим доступу: http://www.rgd. org.ua/project_activities/round_table/round_table_kyiv/PPP_daft_1 
4. Житлово-комунальне господарство чекає на зміни // Інформ. бюл. / Янус Нерухомість. - 2002. - 3. - С. 4-5. - Режим доступу : http://www.proxima.com.ua/ articles/articles.php?clause $=1113$

\section{References:}

1. Bulbas, S. (n.d.). Poriatunok sfery ZhKP - derzhavno-pryvatne partnerstvo [Rescue of housing and communal services - public-private partnership]. www.uspp.org.ua. Retrieved from http://www.uspp.org.ua/interview/17.poryatunok-sferi-zhkg-derzhavno-privatne-partnerstvo.htm [in Ukrainian].

2. Fedotova, Yu.V., Moria, A.O. Derzhavne rehuliuvannia zhytlovo-komunalnoho hospodarstva Ukrainy: svitovyi dosvid ta perspektyvy hospodarstvi [Sovereign regulation of the communal housing of the state of Ukraine: private and prospective statehood]. Zmina paradyhmy pravovoho rehuliuvannia zhytlovo-komunalnoho sektoru ekonomiky ukrainy za chasiv yii nezalezhnosti - Paradigm shift legal control housing and municipal economy of Ukraine since independence : Ukrainian Scientific and Practical Internet conference of young scientists and students. (pp. 136-138). Retrieved from http://ojs.kname.edu.ua/index.php/area/article/view/757 [in Ukrainian].

3. Zakonoproekt Ukrainy "Pro zahalni zasady derzhavno-pryvatnoho partnerstva" : vid 25 cherv. 2009 r. [Bill of Ukraine "On the general principles of public-private partnership" from June 25, 2009]. (n.d.). www.rgd. org.ua. Retrieved from http://www.rgd.org.ua/project_activities/round_table/round_table_kyiv/PPP_daft_1 [in Ukrainian].

4. Zhytlovo-komunalne hospodarstvo chekaie na zminy [Housing and communal services are waiting for changes]. (2002). Yanus Nerukhomist-Janus Real Estate, 3, 4-5. Retrieved from http://www.proxima.com.ua/articles/articles.php?clause=1113 [in Ukrainian]. 